Article

\title{
Conjugation of Lectin to Poly( $\varepsilon$-caprolactone)-block- glycopolymer Micelles for In Vitro Intravesical Drug Delivery
}

\author{
Ning Ning $\mathrm{Li}^{1}{ }^{1}$, Xiao Yan Cai ${ }^{1}$, Jiu Cun Chen ${ }^{1}$, Xue Feng $\mathrm{Hu}^{2, *}$ and $\mathrm{Li}$ Qun $\mathrm{Xu}{ }^{1, *}$ \\ 1 Institute for Clean Energy and Advanced Materials, Faculty of Materials and Energy, Southwest University, \\ Chongqing 400715, China; lny920047@163.com (N.N.L.); cxy921211@163.com (X.Y.C.); \\ chenjc@swu.edu.cn (J.C.C.) \\ 2 National Engineering Research Center for Biomaterials, Sichuan University, Chengdu 610064, China \\ * Correspondence: huxuefeng@scu.edu.cn (X.F.H.); xulq@swu.edu.cn (L.Q.X.); \\ Tel.: +86-28-8541-5280 (X.F.H.); +86-23-6825-4969 (L.Q.X.)
}

Academic Editor: Patrick van Rijn

Received: 22 August 2016; Accepted: 18 October 2016; Published: 26 October 2016

\begin{abstract}
Amphiphilic poly( $\varepsilon$-caprolactone)-block-poly[2-( $\alpha$-D-mannopyranosyloxy) ethyl acrylamide] (PCL- $b$-PManEA) block copolymers were synthesized via a combination of ring-opening polymerization (ROP), reversible addition-fragmentation chain transfer (RAFT) polymerization and reactive ester-amine reaction. The PCL- $b$-PManEA block copolymers can self-assemble into micelles and encapsulate anticancer drug doxorubicin (DOX). To enhance mucoadhesive property of the resulting DOX-loaded PCL- $b$-PManEA micelles, Concanavalin A (ConA) lectin was further conjugated with the micelles. Turbidimetric assay using mucin shows that the DOX-loaded PCL-b-PManEA@ConA micelles are mucoadhesive. DOX release from the DOX-loaded PCL- $b$-PManEA@ConA micelles in artificial urine at $37^{\circ} \mathrm{C}$ exhibits an initial burst release, followed by a sustained and slow release over three days. Confocal laser scanning microscope (CLSM) images indicate that the DOX-loaded PCL-b-PManEA@ConA micelles can be effectively internalized by UMUC3 human urothelial carcinoma cells. The DOX-loaded PCL- $b$-PManEA@ConA micelles exhibit significant cytotoxicity to these cells.
\end{abstract}

Keywords: lectin; glycopolymer; mucoadhesion; reactive pentafluorophenyl ester; bladder cancer; micelles

\section{Introduction}

Bladder cancer is one of the most common malignancies in the world [1,2]. Intravesical chemotherapy via infusion of drugs through urethra into bladder is the most common method for treating early state bladder cancer [1]. However, most of the intravesical drugs are typically maintained intravesically for $2 \mathrm{~h}$, due to voidage of urine after instillation [3]. The lack of success of intravesical chemotherapy is probably due in part to the short drug dwelling time in the bladder and the low drug permeability of the bladder wall [4].

The presence of the mucosal layer on the urothelial surface could be utilized to increase the intravesical drug dwelling time by exploiting the mucoadhesion phenomenon. Mucoadhesion, defined as the ability to adhere to the mucosa-gel layer, is a key element in the development of effective drug delivery systems [5]. The mucoadhesive ability of a dosage form depends on the natural properties of mucosal tissue and the physicochemical properties of the polymeric formulation [6]. Several classes of polymeric materials have been proposed to be mucoadhesive due to their ability to conjugate with the mucosae via non-covalent interactions, such as hydrogen bonds, van-der Waals forces and ionic interactions [7,8]. Much effort has been made to enhance the mucoadhesive properties 
of polymeric formulation via formation of covalent bonds, such as disulfide linkage between the polymer and mucosa [9,10]. Mucoadhesive techniques have further evolved into more specific systems based on lectins [11]. Lectins are proteins or glycoproteins of non-immunological origin, which can bind to specific carbohydrate residues, such as glucose/mannose, $\mathrm{N}$-acetyl-glucosamine, $\mathrm{N}$-acetyl-galactosamine/galactose, L-fucose and sialic acid [12]. These carbohydrate groups are present in glycoproteins of mammalian mucosal layers [13]. Thus, lectin-functionalized formulations could provide specific biological interaction to promote mucoadhesion to the mucosal layer [14,15].

The goal of this work was to synthesize lectin-functionlizable drug-loaded micelles for the intravesical drug delivery. Glycopolymer-block-poly(E-caprolactone) (PCL) copolymers are good choices for this system, as the PCL block can self-assemble in aqueous media and encapsulate anti-cancer drugs and the glycopolymer can conjugate with lectins. Glycopolymer-block-PCL copolymer has been prepared via post-modification of the poly(acryloyl cyclic carbonate)-block-PCL copolymer with thiolated lactobionic acid [16]. It has also been synthesized via atom transfer radical polymerization of unprotected glycomonomer using four-arm PCL as the macroinitiator [17]. Herein, amphiphilic PCL-block-poly[2-( $\alpha$-D-mannopyranosyloxy) ethyl acrylamide] (PCL- $b$-PManEA) block copolymers were prepared via the combination of ring-opening polymerization (ROP), reversible addition-fragmentation chain transfer (RAFT) polymerization and reactive ester-amine reaction. The biodegradable and hydrophobic PCL block was synthesized via ROP of $\varepsilon$-caprolactone. The biocompatible and hydrophilic glycopolymer block was prepared by nucleophilic substitution of the reactive pentafluorophenyl ester group with 2-aminoethyl- $\alpha$-D-mannopyranoside (Scheme 1). The doxorubicin (DOX)-loaded micelles were formed by self-assembly of amphiphilic PCL-b-PManEA block copolymers in aqueous solution and encapsulation of DOX in the micelles. The resulting DOX-loaded PCL-b-PManEA micelles can specifically bind to Concanavalin A (ConA) via lectin-carbohydrate interaction (Scheme 2). After conjugation with the DOX-loaded PCL-b-PManEA micelles, the tetravalent ConA still possesses active sites for further complexation with carbohydrate residues on the mucosal layer. The mucoadhesive properties of the as-synthesized DOX-loaded PCL-b-PManEA@ConA micelles can thus be enhanced. The in vitro drug release, mucoadhesive property, cytotoxicity and cellular uptake by UMUC3 human urothelial carcinoma cells of these DOX-loaded PCL- $b$-PManEA@ConA micelles were investigated.

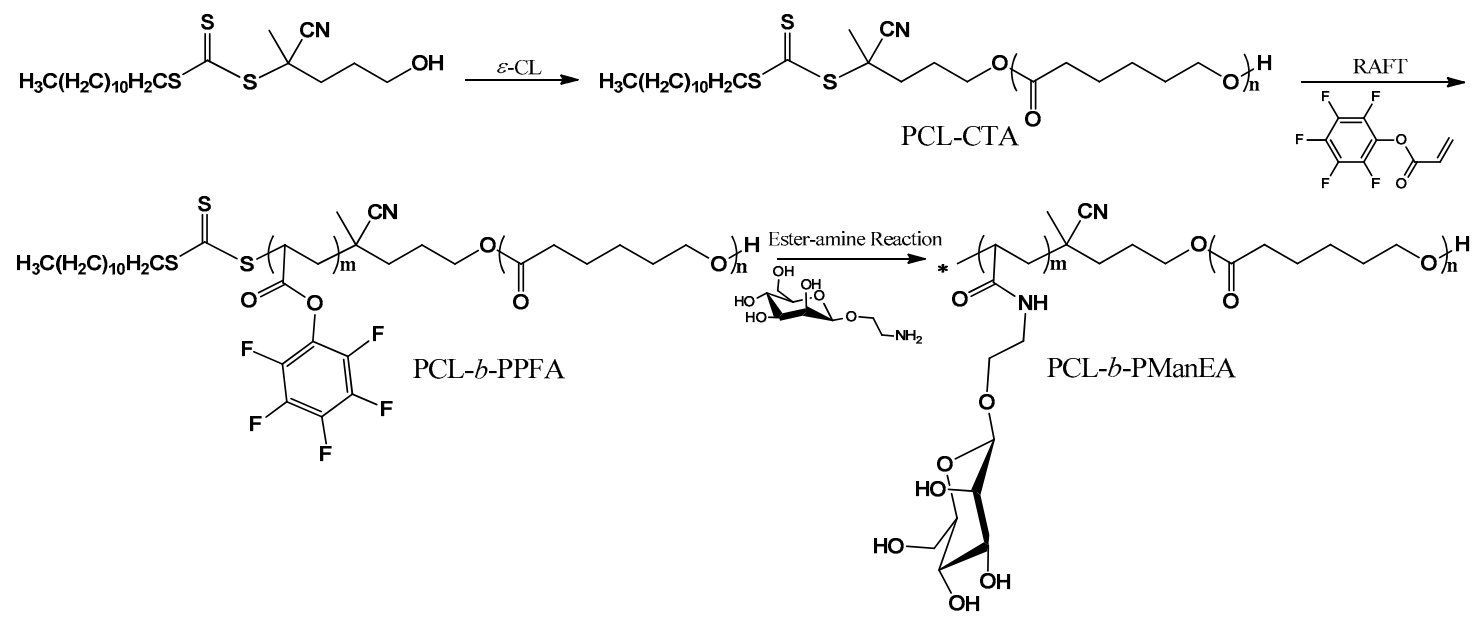

Scheme 1. Synthetic route of poly( $\varepsilon$-caprolactone)-block-poly[2-( $\alpha$-D-mannopyranosyloxy) ethyl acrylamide] (PCL-b-PManEA) block copolymer. 


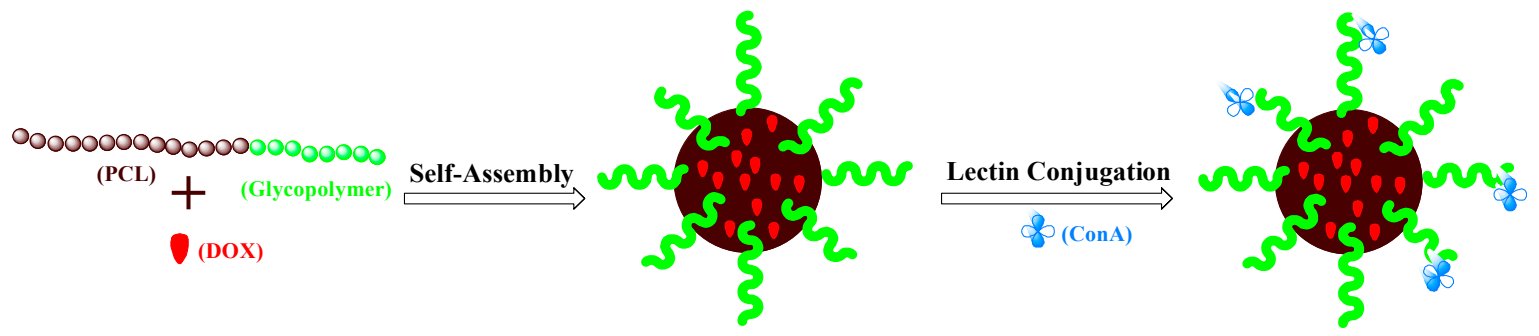

Scheme 2. Self-assembly of PCL- $b$-PManEA block copolymer into micellar nanoparticle and its conjugation with Concanavalin A (ConA) lectin.

\section{Materials and Methods}

\subsection{Materials}

4-Cyano-4-[(dodecylsulfanylthiocarbonyl)sulfanyl]pentanol (CDSP, containing $15 \mathrm{wt} \%$ ethyl acetate as residual solvent), tin(II) 2-ethylhexanoate $\left(\mathrm{Sn}(\mathrm{Oct})_{2}, 95 \%\right), \varepsilon$-caprolactone $(\varepsilon-\mathrm{CL}, 99 \%)$, concanavalin A (ConA, Type VI, lyophilized powder) lectin, mucin from porcine stomach (type II) and 2,2'-azoisobutyronitrile (AIBN, 98\%) were purchased from Sigma-Aldrich Chemical Co (St. Louis, MO, USA), Doxorubicin (DOX) hydrochloric acid salt (DOX. $\mathrm{HCl}, 99 \%)$ was purchased from LC Laboratories (Woburn, MA, USA). All other regents were purchased from Sigma-Aldrich or Merck Chem. Co. (Darmstadt, Germany), and were used without further purification. Pentafluorophenyl acrylate (PFA) and 2-aminoethyl- $\alpha$-D-mannopyranoside were synthesized according to the methods reported in the literature $[18,19]$.

\subsection{Synthesis of Poly(e-caprolactone) (PCL) Macro-Chain Transfer Agent (Macro-CTA)}

PCL macro-CTA was synthesized by ring-opening polymerization (ROP) of $\varepsilon$-CL using $\mathrm{Sn}(\mathrm{Oct})_{2}$ as a catalyst and CDSP as an initiator. CDSP $\left(200.0 \mathrm{mg}, 5.1 \times 10^{-4} \mathrm{~mol}\right)$ and $\varepsilon-\mathrm{CL}\left(5.6 \mathrm{~mL}, 5.1 \times 10^{-2} \mathrm{~mol}\right)$ were charged into a 50-mL Schlenk flask equipped with a magnetic stirring bar. A solution of $\mathrm{Sn}(\mathrm{Oct})_{2}$ ( $40.5 \mathrm{mg}, 1.0 \times 10^{-4} \mathrm{~mol}$ ) in $2 \mathrm{~mL}$ of toluene was also added using a syringe. The reaction mixture was degassed with argon for $20 \mathrm{~min}$, sealed, and stirred at $110{ }^{\circ} \mathrm{C}$ for $12 \mathrm{~h}$. The flask was then immersed in an ice bath to stop the reaction. The resulting solid was dissolved with $10 \mathrm{~mL}$ of tetrahydrofuran (THF) and then poured into $200 \mathrm{~mL}$ of cold diethyl ether to precipitate the polymer. The precipitate was filtered, followed by drying under reduced pressure at room temperature for $24 \mathrm{~h}$. The resulting PCL samples prepared from (CDSP):( $(\varepsilon-C L)$ molar feed ratios of 1:100 and 1:150 are referred to as PCL1 and PCL2, respectively. The number-average molecular weights $\left(M_{n}\right)$ of PCL1 and PCL2 were determined from gel permeation chromatography (GPC, Waters Co., Milford, MA, USA) analysis to be 8800 and $12,800 \mathrm{~g} / \mathrm{mol}$, respectively.

\subsection{Reversible Addition-Fragmentation Chain Transfer (RAFT) Polymerization of PFA Using PCL as the Macro-CTA}

The PCL macro-CTA (PCL1, $1.3 \mathrm{~g}, 1.5 \times 10^{-4} \mathrm{~mol}$; or PCL2, $1.9 \mathrm{~g}, 1.5 \times 10^{-4} \mathrm{~mol}$ ) was first dissolved in $8 \mathrm{~mL}$ of toluene in a $25 \mathrm{~mL}$ round-bottom flask under magnetic stirring. Subsequently, AIBN $\left(6.2 \mathrm{mg}, 3.8 \times 10^{-5} \mathrm{~mol}\right)$ and PFA $\left(1.8 \mathrm{~g}, 7.5 \times 10^{-3} \mathrm{~mol}\right)$ were added into the above mixture under vigorous stirring. The reaction mixture was degassed with argon for $30 \mathrm{~min}$. The flask was sealed and kept in a $70{ }^{\circ} \mathrm{C}$ oil bath under stirring for $12 \mathrm{~h}$. The reaction mixture was then cooled in an ice bath, diluted with $10 \mathrm{~mL}$ of THF, and precipitated into $200 \mathrm{~mL}$ of cold ethanol. The precipitate was filtered, washed with ethanol, followed by drying under reduced pressure at room temperature for $24 \mathrm{~h}$. The obtained PCL-block-poly(PFA) (PCL- $b$-PPFA) block copolymers from PCL1 macro-CTA and PCL2 macro-CTA are referred to as PCL1- $b$-PPFA and PCL2- $b$-PPFA, respectively. The $M_{n}$ s of PCL1- $b$-PPFA and PCL2- $b$-PPFA were determined from GPC analysis to be 12,500 and 16,100 g/mol, respectively. 


\subsection{Synthesis of PCL-block-poly[2-( $\alpha$-D-mannopyranosyloxy) ethyl acrylamide] (PCL-b-PManEA) Block Copolymers}

PCL- $b$-PManEA block copolymers were prepared by post-functionalization of the respective PCL- $b$-PPFA block copolymers with 2-aminoethyl- $\alpha$-D-mannopyranoside via reactive ester-amine reaction. The PCL1- $b$-PPFA block copolymer $\left(1.0 \mathrm{~g}, 1.3 \times 10^{-3} \mathrm{~mol}\right.$ of PFA repeat units), triethylamine $\left(0.3 \mathrm{~mL}, 2.1 \times 10^{-3} \mathrm{~mol}\right), 2$-aminoethyl- $\alpha$-D-mannopyranoside $(150 \mathrm{~mol} \%$ relative to PFA repeat units, $0.6 \mathrm{~g}, 2.1 \times 10^{-3} \mathrm{~mol}$ ) and dry $\mathrm{N}, \mathrm{N}$-dimethylformamide (DMF, $10 \mathrm{~mL}$ ) were added into a $25 \mathrm{~mL}$ round-bottom flask. Excess 2-aminoethyl- $\alpha$-D-mannopyranoside was used to ensure the complete conversion of pentafluorophenyl ester groups. The reaction mixture was stirred at $50{ }^{\circ} \mathrm{C}$ for $24 \mathrm{~h}$ under an argon atmosphere. After that, the flask was cooled down to room temperature and the polymer was precipitated into $200 \mathrm{~mL}$ of cold ethanol. The obtained polymer was filtered and re-dissolved in $20 \mathrm{~mL}$ of DMF. The re-dissolution and precipitation process was repeated three times to remove any residual reactant adducts. About $0.7 \mathrm{~g}$ of the PCL1- $b$-PManEA copolymer was obtained after drying under reduced pressure at room temperature for $24 \mathrm{~h}$. The corresponding sample prepared from PCL2- $b$-PPFA block copolymer is referred to as PCL2- $b$-PManEA block copolymer.

\subsection{Preparation of DOX-Loaded PCL-b-PManEA Micelles}

DOX. $\mathrm{HCl}(10 \mathrm{mg})$, triethylamine $(5.0 \mu \mathrm{L})$ and PCL- $b$-PManEA block copolymer $(100 \mathrm{mg})$ were dissolved in $10 \mathrm{~mL}$ of DMF. The mixture was stirred at $25^{\circ} \mathrm{C}$ for $2 \mathrm{~h}$, and then added dropwise to $50 \mathrm{~mL}$ of doubly distilled water under vigorous stirring at $25^{\circ} \mathrm{C}$. The solution was further sonicated for $10 \mathrm{~min}$ and stirred at $25^{\circ} \mathrm{C}$ for $4 \mathrm{~h}$. After that, the micelle solution was dialyzed against doubly distilled water (molecular weight cutoff $=3500 \mathrm{Da}$ ) for $24 \mathrm{~h}$. During dialysis, the water was renewed every $4 \mathrm{~h}$. The resulting DOX-loaded PCL- $b$-PManEA micelles from PCL1- $b$-PManEA and PCL2- $b$-PManEA block copolymers are referred to as DOX-loaded PCL1- $b$-PManEA and PCL2-b-PManEA micelles, respectively. For determination of drug loading, the DOX-loaded PCL- $b$-PManEA micelles were analyzed by UV-visible absorption spectroscopy (Hitachi U2800 spectrophotometer, Hitachi Ltd., Tokyo, Japan) at the wavelength of $480 \mathrm{~nm}$. The calibration curve ( $y$ (absorption intensity) $=17.341 \times$ $x(\mathrm{mg} / \mathrm{mL})+0.004)$ was obtained using $\mathrm{DOX} \cdot \mathrm{HCl}$ aqueous solutions of different concentrations. The drug loadings of DOX-loaded PCL1- $b$-PManEA and PCL2- $b$-PManEA micelles were determined to be 3.60 and $3.61 \mathrm{wt} \%$, respectively. Solid DOX-loaded PCL-b-PManEA micelles were obtained by freeze-drying. DOX-free PCL1- $b$-PManEA micelles were prepared via a similar procedure in the absence of DOX and triethylamine.

\subsection{Preparation of DOX-Loaded PCL-b-PManEA Micelles-ConA Conjugates (DOX-Loaded PCL-b-PManEA@ConA Micelles)}

DOX-loaded PCL-b-PManEA micelles (30 mg) were dispersed in $30 \mathrm{~mL}$ of doubly distilled water in a $50 \mathrm{~mL}$ round-bottom flask with the aid of sonication for $2 \mathrm{~min}$. An aqueous solution of $1.5 \mathrm{mg} / \mathrm{mL}$ of ConA was prepared, and $4 \mathrm{~mL}$ of the ConA solution was transferred into the flask. The solution in the flask was thoroughly mixed via vigorous stirring for $15 \mathrm{~min}$ and immediately returned to the freeze-dryer to obtain the solid DOX-loaded PCL-b-PManEA@ConA micelles. The respective DOX-loaded PCL1- $b$-PManEA and PCL2- $b$-PManEA micelles-ConA conjugates are referred to as DOX-loaded PCL1-b-PManEA@ConA and PCL2-b-PManEA@ConA micelles. DOX-free PCL1-b-PManEA@ConA micelles were prepared from DOX-free PCL1-b-PManEA micelles in a similar manner.

\subsection{In Vitro Drug Release}

Fifteen milligrams of DOX-loaded PCL- $b$-PManEA@ConA micelles were dispersed in $15 \mathrm{~mL}$ of respective phosphate buffered saline (PBS, $\mathrm{pH}=7.4)$ and artificial urine $(\mathrm{AU}, \mathrm{pH}=6.1)$. AU was prepared according to the method reported in the literature [20]. Ten milliliters of the respective DOX-loaded PCL-b-PManEA@ConA micelles dispersions were transferred into dialysis bags with a 
molecular weight cut-off of 3500 Daltons (Spectrum Labs). The dialysis bags were then immersed into $10 \mathrm{~mL}$ of the corresponding media (PBS or AU) in 50-mL centrifuge tubes with gentle shaking $(100 \mathrm{rpm})$ at $37^{\circ} \mathrm{C}$. At predetermined time intervals, $10 \mathrm{~mL}$ of the media outside the dialysis bags were extracted, and were replaced by fresh media. The release experiments were conducted for $72 \mathrm{~h}$ in PBS and AU. The released DOX amounts were determined by UV-visible absorption spectroscopy based on the absorption intensity at the wavelength of $480 \mathrm{~nm}$ for samples in PBS and AU. The calibration curves for DOX in PBS and AU were $(y$ (absorption intensity) $=14.794 \times x(\mathrm{mg} / \mathrm{mL})-0.002)$ and $(y$ (absorption intensity $)=10.194 \times x(\mathrm{mg} / \mathrm{mL})+0.003)$, respectively.

\subsection{Cell Culture and Incubation}

The UMUC3 human urothelial carcinoma cell line, purchased from American Type Culture Collection (ATCC, Manassas, VA, USA), were cultivated in Dulbecco's modified Eagle's medium (DMEM) at $37^{\circ} \mathrm{C}$ in a humidified environment of $5 \% \mathrm{CO}_{2}$. The medium was changed every two days until cell confluence was reached.

\subsection{Cell Viability}

The cytotoxicities of free DOX, DOX-free and DOX-loaded PCL1- $b$-PManEA@ConA micelles towards UMUC3 cells were determined from the assay based on the reduction of 3-(4,5-dimethylthiazol-2-yl)-2,5-diphenyltetrazolium bromide (MTT) reagent. The MTT assay was performed in a 96-well plate following the standard procedure with minor modifications. The cells were seeded at a density of 3000 cells per well and incubated at $37^{\circ} \mathrm{C}$ for $24 \mathrm{~h}$. The medium was then replaced by one containing free DOX with drug concentrations ranging from $1.5 \times 10^{-3}$ to $100 \mu \mathrm{g} / \mathrm{mL}$ or DOX-loaded PCL-b-PManEA@ConA micelles with micelles concentrations ranging from $3.0 \times 10^{-5}$ to $2.0 \mathrm{mg} / \mathrm{mL}$ for $2 \mathrm{~h}$. Control experiments were carried out using the complete growth culture medium, without free DOX or micelles. After that, the culture medium in each well was removed. The cells were washed thrice with PBS, and $100 \mu \mathrm{L}$ of fresh culture medium was added into each well. After $72 \mathrm{~h}$ of incubation at $37^{\circ} \mathrm{C}$, the medium was removed, and $100 \mu \mathrm{L}$ of MTT solution $(0.5 \mathrm{mg} / \mathrm{mL}$ in DMEM medium) were added to each well. After an additional $4 \mathrm{~h}$ of incubation, culture supernatants were aspirated, and the formazan crystals were dissolved with $100 \mu \mathrm{L}$ of dimethyl sulfoxide (DMSO) for $15 \mathrm{~min}$. The optical absorbance was then measured at $600 \mathrm{~nm}$ on a microplate reader (Tecan GENios, Tecan Asia Ltd., Grödig, Austria). The results were expressed as percentages relative to that obtained in the control experiment.

\subsection{Cellular Uptake}

For cellular uptake experiments, UMUC3 cells were seeded on glass dishes at a density of $5 \times 10^{4}$ cells for $24 \mathrm{~h}$. The medium was then aspirated and replaced with media containing DOX-loaded PCL1-b-PManEA@ConA micelles at a concentration of $2 \mathrm{mg} / \mathrm{mL}$ in the absence and presence of 1-methyl $\alpha$-D-mannopyranoside (MeMan, $20 \mathrm{mM}$ ). The cells were cultured for another $2 \mathrm{~h}$, and washed thrice with sterilized doubly distilled water to remove the physically adsorbed DOX-loaded PCL1-b-PManEA@ConA micelles completely. After that, the cells were fixed in formaldehyde aqueous solution $(4 \%, v / v)$ for $30 \mathrm{~min}$. Following fixation, the cells were observed on a Nikon (A1) Confocal Laser Scanning Microscope (CLSM, Nikon, Tokyo, Japan). For fluorescence imaging, the cells were excited at $488 \mathrm{~nm}$, and the fluorescence in the wavelength region of 570-620 nm was recorded.

\subsection{Mucoadhesive Property of DOX-loaded PCL1-b-PManEA@ConA Micelles}

The mucoadhesive property of DOX-loaded PCL1-b-PManEA@ConA micelles was evaluated using the turbidimetric assay. One milligram per milliliter of mucin from porcine stomach was first prepared in phosphate-buffered saline (PBS, $\mathrm{pH}=7.4$ ). One and half milliliters of this mucin solution was transferred into a quartz cell and placed into the holding block of the spectrometer 
(Hitachi U2800 spectrophotometer). One and half milliliters of the DOX-loaded PCL1- $b$-PManEA micelles, or DOX-loaded PCL1-b-PManEA@ConA micelles (1 mg/mL in PBS, pH = 7.4), was added into the quartz cell containing the mucin solution. The mixture in the quartz cell was mixed using a vortex mixer and immediately returned to the holding block, where the transmittance at $420 \mathrm{~nm}$ was continuously monitored for $2 \mathrm{~h}$. The starting transmittance of each sample was set as $100 \%$. The controlled experiment was carried out using mucin, DOX-loaded PCL1- $b$-PManEA micelles or DOX-loaded PCL1- $b$-PManEA@ConA micelles $(0.5 \mathrm{mg} / \mathrm{mL})$ only. In the absence of mucin, the turbidity of DOX-loaded PCL1-b-PManEA micelles and DOX-loaded PCL1-b-PManEA@ConA micelles changed by less than $2 \%$ after 1 day (data not shown). The competitive binding assays for free ConA $(0.5 \mathrm{mg} / \mathrm{mL})$ and DOX-loaded PCL1-b-PManEA@ConA micelles $(1 \mathrm{mg} / \mathrm{mL})$ were carried out in the presence of MeMan (20 mM).

\subsection{Characterization}

The chemical structures of obtained polymers were characterized by ${ }^{1} \mathrm{H}$ NMR spectroscopy on a Bruker DRX $400 \mathrm{MHz}$ spectrometer (Bruker UK Ltd., Coventry, UK). Gel permeation chromatography (GPC) was performed on a Waters GPC system, equipped with a Waters 1515 isocratic HPLC pump, a Waters 717 plus Autosampler injector, a Waters 2414 refractive index detector and a PLgel $10 \mu \mathrm{m}$ Mixed-B column (Agilent Technologies, S/N 10M-MB-D7-9K8), using THF as the eluent at a flow rate of $1.0 \mathrm{~mL} / \mathrm{min}$ at $35^{\circ} \mathrm{C}$. X-ray photoelectron spectroscopy (XPS) measurements were carried out on a Kratos AXIS Ultra HSA spectrometer (Kratos Analytical Ltd., Manchester, UK) equipped with a monochromatized AlK $\alpha$ X-ray source (1468.71 eV photons). Field-emission transmission electron microscopy (FETEM) images were obtained from a JEOL JEM-2010 FETEM (JEOL Ltd., Tokyo, Japan). Aqueous samples were drop-casted on copper TEM grids, followed by drying under reduced pressure for $12 \mathrm{~h}$. FT-IR spectroscopy analysis was carried out on a Bio-Rad FTS-135 spectrophotometer (Bio-Rad Laboratories Inc., Cambridge, MA, USA). Dynamic light scattering (DLS) measurements were performed on a Brookhaven 90 plus laser light scattering spectrometer (Brookhaven Instruments Co., Holtsville, NY, USA) at a scattering angle of $90^{\circ}$. Aqueous samples were sonicated in the water bath for $2 \mathrm{~min}$. Loaded samples were then diluted by doubly distilled water to make sure that the particles count rate was within the range of 200-700 kcps. For every sample, five runs were conducted. The measurement was carried out at $25^{\circ} \mathrm{C}$ with the final results being given as the average of the five analyses for each sample plus its standard derivation. The effective diameters were calculated by ZetaPlus Particle Sizing Software Version 3.93 (Brookhaven Instruments Co., Holtsville, NY, USA).

\section{Results and Discussion}

\subsection{Synthesis of PCL-b-PManEA Block Copolymers}

There are many methods for the synthesis of homo/block glycopolymers, including conventional radical polymerization, living ionic polymerization, ring-opening metathesis polymerization (ROMP) and controlled radical polymerization (CRP) [21,22]. These techniques usually include procedures for the protection of glycomonomers and deprotection of the resulting homo/block glycopolymers [23]. To simplify the synthetic approach to glycopolymers, post-functionalization of a preformed polymer/copolymer using active sugar moieties is desirable. The active pentafluorophenyl esters are advantageous for post-modification [24-26], and will be suitable for building up the glycopolymer structures. In the present work, the combination of ROP, RAFT polymerization and reactive ester-amine reaction was utilized to synthesize the PCL- $b$-PManEA block copolymers. The detailed synthesis route, which consists of three consecutive steps, was shown in Scheme 1.

PCL macro-CTA was synthesized via ROP of $\varepsilon$-CL using CDSP as the initiator and $\mathrm{Sn}(\mathrm{Oct})_{2}$ as the catalyst. The resulting PCL macro-CTAs prepared from (CDSP):( $\varepsilon-C L)$ molar feed ratios of 1:100 and 1:150 are referred to as PCL1 and PCL2, respectively. The $M_{\mathrm{n}} \mathrm{s}$ of PCL1 and PCL2, as determined by GPC, were 8800 and $12,800 \mathrm{~g} / \mathrm{mol}$ respectively, with a polydispersity index (PDI) of about 1.50 
(Supplementary Materials Table S1 and Figure S1). In the future work, other catalysts should be chosen to obtain the PCL homopolymers with narrow molecular weight distributions and good chain extension efficiency. Figure 1a shows the ${ }^{1} \mathrm{H}$ NMR spectrum of PCL1 in $\mathrm{CDCl}_{3}$. The chemical shifts at 4.05, 2.30, 1.64 and $1.37 \mathrm{ppm}$ are characteristic signals of PCL repeating units [27]. In addition, the chemical shift at about $0.90 \mathrm{ppm}$ is assigned to the methyl proton of CDSP, indicating that the CTA's persist in the PCL samples.

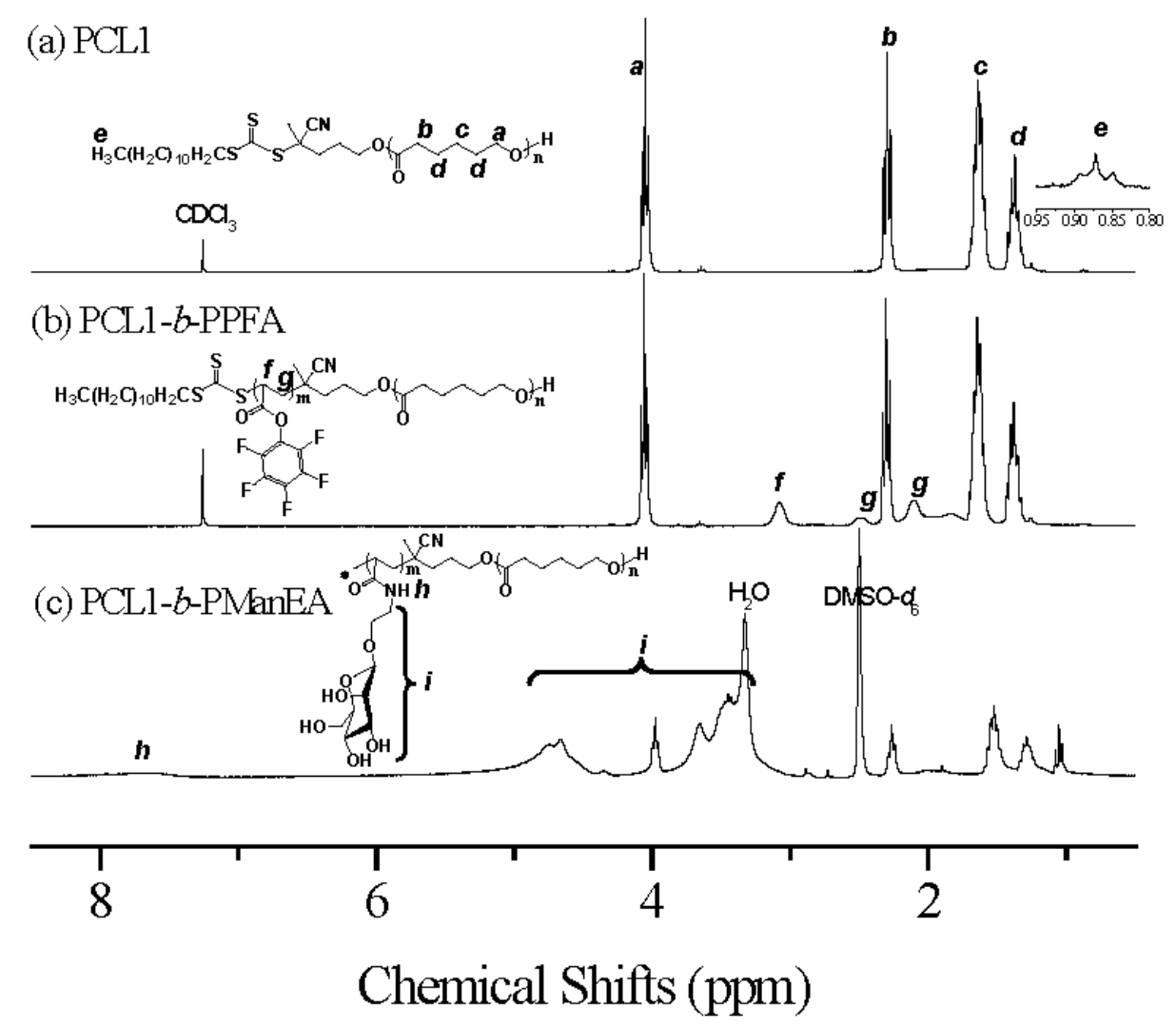

Figure 1. ${ }^{1} \mathrm{H}$ NMR spectra of: (a) PCL1 homopolymer; (b) PCL1- $b$-PPFA; and (c) PCL1- $b$-PManEA block copolymers.

These PCL samples were then utilized as macro-CTAs to mediate RAFT polymerization of PFA, using AIBN as the initiator. Successful block copolymerization of PFA was confirmed by GPC, ${ }^{1} \mathrm{H}$ NMR spectroscopy, FT-IR spectroscopy and XPS measurement. The GPC elution curves of PCL1- $b$-PPFA and PCL2- $b$-PPFA are shown in Figure S1 (Supplementary Materials). The respective $M_{n}$ has increased substantially after block copolymerization, as indicated by the shifting of the GPC elution curve to shorter time. The ${ }^{1} \mathrm{H}$ NMR spectrum of PCL1-b-PPFA (Figure 1b) shows the resonances of methine and methylene protons on the backbone of PPFA. These results indicate that the PFA monomers have been successfully copolymerized. From the integrated area ratio of the signal due to the methylene group in PCL repeating units at $4.05 \mathrm{ppm}$ and the signal due to the methine group in PPFA backbone at $3.07 \mathrm{ppm}$, the molar ratios of PCL block to PPFA block are calculated to be about 1.49:1 and 2.38:1 for PCL1-b-PPFA and PCL2- $b$-PPFA, respectively. The absorption bands at 1790 and $1524 \mathrm{~cm}^{-1}$ in the FT-IR spectrum of PCL1- $b$-PPFA (Figure $2 b$ ) are assigned to the stretches of reactive ester moiety and pentafluorophenyl group in the PPFA block, respectively. The presence of F 1s signal at the binding energy (BE) of about $690 \mathrm{eV}$ in the XPS wide-scan spectrum of PCL1-b-PPFA (Figure 3b) and fluorine signals in the ${ }^{19} \mathrm{~F}$ NMR spectrum of PCL1-b-PPFA (Figure S4a, Supplementary Materials) also indicates that the block copolymers have been successfully synthesized. 


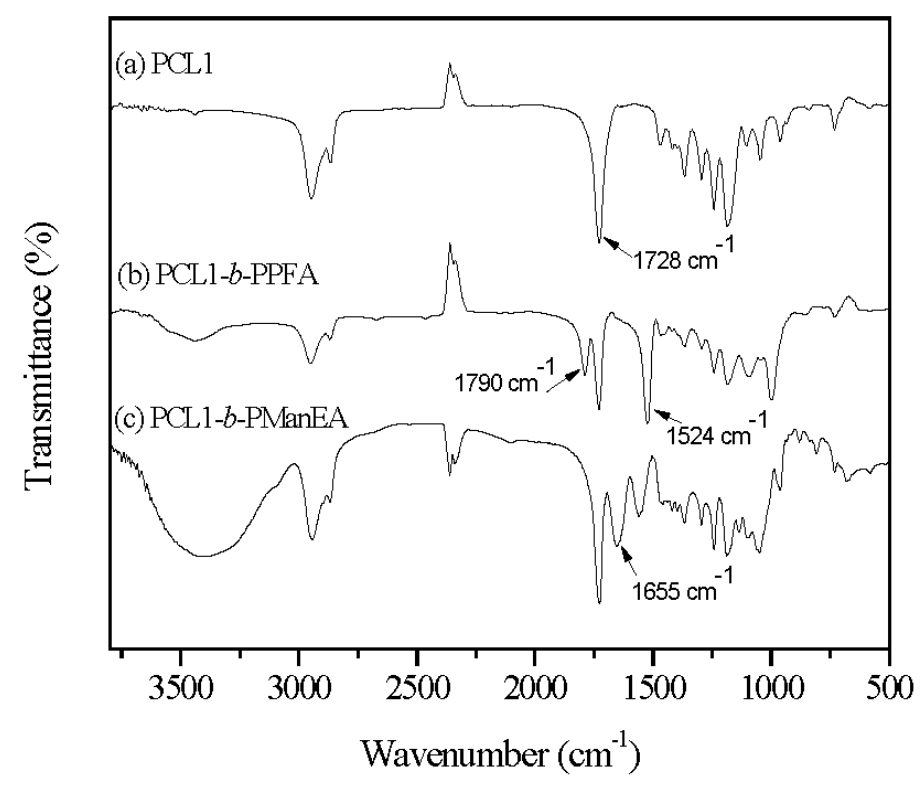

Figure 2. FT-IR spectra of: (a) PCL1 homopolymer; (b) PCL1- $b$-PPFA; and (c) PCL1- $b$-PManEA block copolymers.

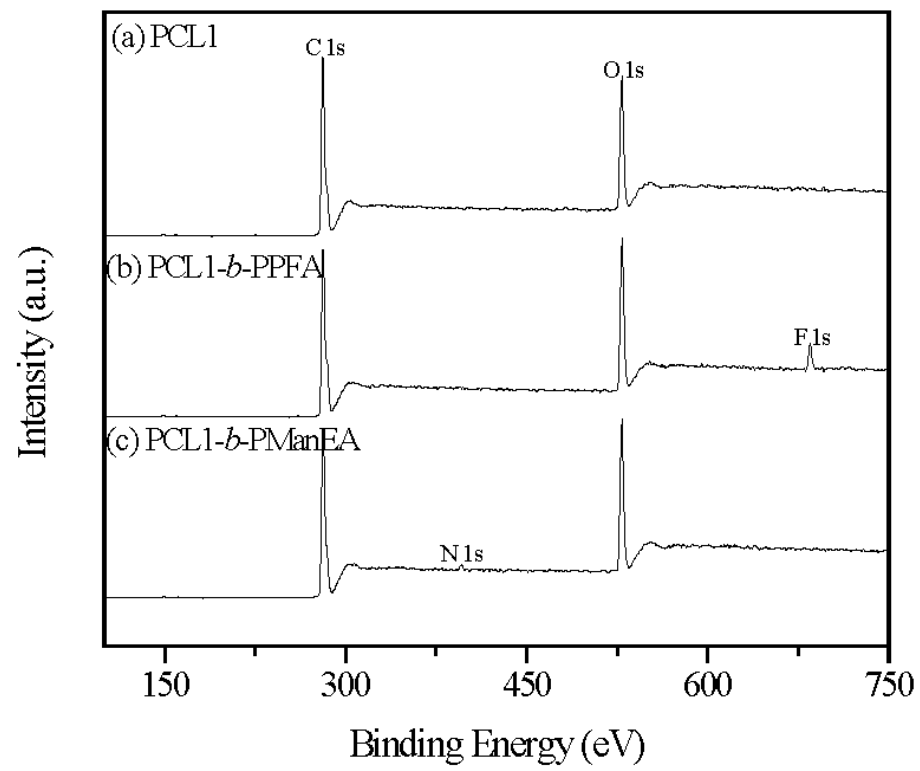

Figure 3. X-ray photoelectron spectroscopy (XPS) wide-scan spectra of: (a) PCL1 homopolymer; (b) PCL1- $b$-PPFA; and (c) PCL1- $b$-PManEA block copolymers.

The PCL- $b$-PPFA block copolymers were further reacted with 2-aminoethyl- $\alpha$-Dmannopyranoside via reactive ester-amine reaction, leading to the formation of PCL-b-PManEA block copolymers. An excess of 2-aminoethyl- $\alpha$-D-mannopyranoside was added to ensure complete conversion. The obtained PCL- $b$-PManEA block copolymers from PCL1- $b$-PPFA and PCL2- $b$-PPFA are referred to as PCL1- $b$-PManEA and PCL2- $b$-PManEA, respectively. Figure $1 \mathrm{c}$ shows the ${ }^{1} \mathrm{H}$ NMR spectrum of PCL1- $b$-PManEA in DMSO- $d_{6}$. The chemical shifts in the range of 7.53-7.96 ppm are related to the $\mathrm{NH}$ proton of the amide group. The shifts in the region of 2.98-5.18 ppm are attributable to the protons of $\mathrm{C}-\mathrm{H}$ and $\mathrm{OH}$ in carbohydrate and ethylene linker between amide and carbohydrate. Figure $2 c$ shows the FT-IR spectrum of PCL1- $b$-PManEA. The appearance of hydroxyl band above $3000 \mathrm{~cm}^{-1}$, the disappearance of reactive ester stretch at $1790 \mathrm{~cm}^{-1}$ and the presence of amide peak at 
$1648 \mathrm{~cm}^{-1}$, confirm the successful conversion of reactive ester group into amide group and also the presence of pendant carbohydrate moieties in the PCL- $b$-PManEA block copolymers. XPS analysis of the PCL1- $b$-PManEA copolymers was also carried out to verify the reaction of reactive ester groups of PPFA with 2-aminoethyl- $\alpha$-D-mannopyranoside. Figure $3 c$ shows the XPS wide-scan spectrum of PCL1- $b$-PManEA. In comparison to the XPS wide-scan spectrum of PCL1- $b$-PPFA precursor (Figure 3b), the appearance of the $\mathrm{N} 1 \mathrm{~s}$ signal at the $\mathrm{BE}$ of about $400 \mathrm{eV}$ and the disappearance of $\mathrm{F} 1 \mathrm{~s}$ signal at the BE of about $690 \mathrm{eV}$ in PCL1-b-PManEA (Figure 3c) are consistent with the successful conversion of the reactive ester groups to amide groups.

\subsection{Preparation of DOX-Loaded PCL-b-PManEA Micelles and Their Lectin Conjugates}

The physical entrapment of DOX (one of the common chemotherapeutic agents for intravesical treatment of bladder cancer [28]) into the PCL- $b$-PManEA micelles was performed by a dialysis technique [29]. For efficient encapsulation in the micelles, DOX hydrochloric acid salt (DOX. $\mathrm{HCl})$ is usually deprotonated by triethylamine, which removes the positive charge and enhances hydrophobicity of DOX molecule [30]. The amount of drug encapsulated into the micelles was determined by UV-visible absorption spectroscopy using a calibration curve. A DOX loading of about 3.6 wt \% was obtained for the PCL1-b-PManEA and PCL2-b-PManEA micelles under the same condition.

The size and morphology of DOX-loaded PCL1-b-PManEA and PCL2- $b$-PManEA micelles were subsequently analyzed by DLS and FETEM. The hydrodynamic diameter distribution functions of DOX-loaded PCL1- $b$-PManEA and PCL2- $b$-PManEA micelles, obtained from DLS measurements at $90^{\circ}$ scattering angle, are shown in Figure S5a,b (Supplementary Materials). DLS results show that DOX-loaded PCL1- $b$-PManEA and PCL2- $b$-PManEA micelles exhibit unimodal size distribution with the mean effective diameter increases from 117.7 to $152.4 \mathrm{~nm}$ as the $M_{\mathrm{n}}$ of PCL block increases from 8000 to $12,800 \mathrm{~g} / \mathrm{mol}$. This result indicates that a longer PCL block can lead to a larger micelle core [31]. The observation was further supported by the respective FETEM image of DOX-loaded PCL1-b-PManEA and PCL2- $b$-PManEA micelles (Figure S5c,d, Supplementary Materials). From the FETEM image, the DOX-loaded PCL1-b-PManEA micelles are close to spherical shape, with an average diameter of about $48 \mathrm{~nm}$. The DOX-loaded PCL2-b-PManEA micelles have an average diameter of about $89.2 \mathrm{~nm}$ and the micelle morphology is irregular. Furthermore, the average diameter of the micelles observed from FETEM image is smaller than that obtained from DLS measurement. As the FETEM measurements were performed in dry state, the micelles were dehydrated, and the hydrophilic shells collapsed on the hydrophobic cores.

Another objective of present study is to conjugate lectin to the DOX-loaded PCL-b-PManEA micelles to enhance their mucoadhesive property. It is known that concanavalin A (ConA) lectin can specifically recognize D-glucopyranoside and D-mannopyranoside moieties [32]. Thus, the D-mannopyranoside moieties in the corona of PCL- $b$-PManEA micelles can readily complex with ConA to produce the DOX-loaded PCL-b-PManEA micelles-ConA conjugates (DOX-loaded PCL-b-PManEA@ConA micelles). Scheme 2 depicts the conjugation of DOX-loaded PCL-b-PManEA micelles with ConA. The successful conjugation was monitored from the evolution of mean effective diameters of DOX-loaded PCL1- $b$-PManEA and PCL2- $b$-PManEA micelles upon binding with ConA (Figure S6, Supplementary Materials). The mean effective diameters of both micelles grow with the increase in conjugation time and reach a plateau after about 5 and $10 \mathrm{~min}$ for DOX-loaded PCL1-b-PManEA and PCL2- $b$-PManEA micelles, respectively. This phenomenon may be arising from the smaller particle size of PCL1-b-PManEA micelles, providing larger surface area for ConA conjugation.

\subsection{In Vitro Drug Release}

The drug release from polymeric micelles is frequently studied using a method in which drug-loaded micelles are entrapped inside a dialysis bag and only the released drug could pass 
through the dialysis membrane [33]. This method was utilized in this study, and the release of DOX from DOX-loaded PCL1- $b$-PManEA and PCL2- $b$-PManEA@ConA micelles was assessed at $37^{\circ} \mathrm{C}$ in phosphate buffered saline (PBS, $\mathrm{pH}=7.4$ ) and artificial urine ( $\mathrm{AU}, \mathrm{pH}=6.1$ ) for $72 \mathrm{~h}$. The cumulative release curves of DOX are shown in Figure 4. The maximum DOX release in PBS and AU are 29.2\% and $82.9 \%$ for DOX-loaded PCL1-b-PManEA@ConA micelles, and 20.2\% and 56.8\% for DOX-loaded PCL2-b-PManEA@ConA micelles, respectively. In general, the release profiles show an initial burst release of DOX, followed by a sustained and slow release over a prolonged period of time. The initial burst release of DOX from micelles could be attributed to the diffusion of DOX located close to the surface of the micelles, or within the hydrophilic corona, or degradation of the micelles [34]. The total drug released in AU is significantly higher than that in PBS. This phenomenon is due to the higher ionic strength and lower $\mathrm{pH}$ of $\mathrm{AU}$ [35], which accelerates the hydrolysis of ester moieties in the PCL blocks [36,37]. Furthermore, lower DOX release in both PBS and AU are observed from DOX-loaded PCL2-b-PManEA@ConA micelles, which has longer hydrophobic PCL blocks. This result suggests that the release of DOX can be controlled by the hydrophobic PCL chain length, as was also found previously for chitosan- $g$-polydioxane copolymers and oligoagarose-g-PCL copolymers [38,39].
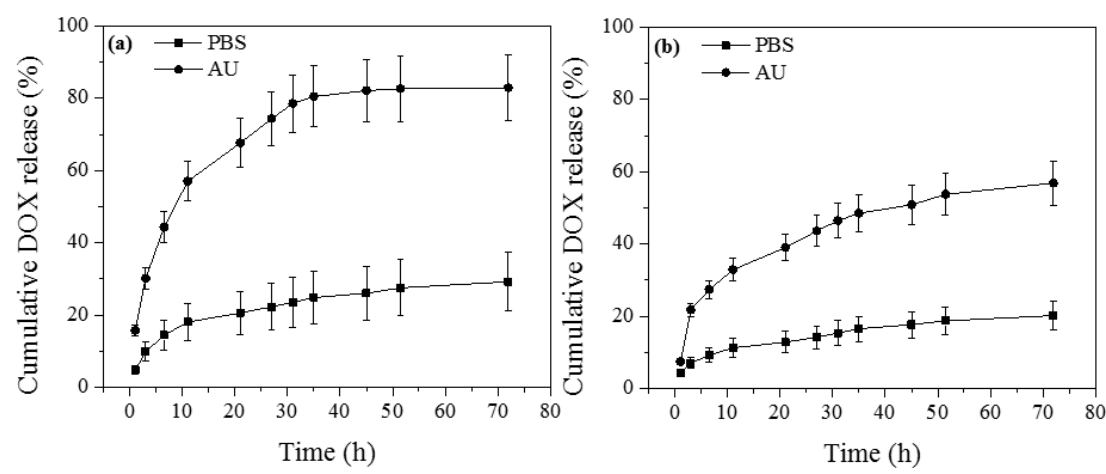

Figure 4. Cumulative DOX release from: (a) DOX-loaded PCL1- $b$-PManEA@ConA micelles; and (b) DOX-loaded PCL2-b-PManEA@ConA micelles in phosphate buffered saline (PBS) and artificial urine (AU).

\subsection{Mucoadhesive Study}

The mucoadhesive property of DOX-loaded PCL1-b-PManEA@ConA micelles was tested by a turbidimetric assay using mucin from porcine stomach as the model mucin. Upon binding of micelles to mucin, the mucin size will increase, leading to a decrease in the transmittance of the mucin-micelles aqueous solution. Figure 5 shows the turbidimetric assay curves of DOX-loaded PCL1- $b$-PManEA micelles, and free ConA and DOX-loaded PCL1-b-PManEA@ConA micelles in the presence and absence of 1-methyl $\alpha$-D-mannopyranoside (MeMan), with mucin. A control experiment was carried out using mucin or micelles only. Mucin alone does not cause an increase in turbidity (Figure 5, curve c). No obvious increase in turbidity was observed for DOX-loaded PCL1-b-PManEA micelles and mucin mixture (Figure 5, curve d). Thus, interaction between the ConA-deficient micelles and mucin is weak or absent. Conversely, the turbidity of DOX-loaded PCL1- $b$-PManEA@ConA micelles and mucin mixture increases within $2 \mathrm{~h}$, suggesting that mucin-ConA interaction has occurred (Figure 5, curve e). After having shown that DOX-loaded PCL1- $b$-PManEA@ConA micelles can interact with mucin, it is important to test the ConA-mediated mucoadhesion via the competitive assays using MeMan, a competitive sugar for ConA [40]. MeMan can compete with the carbohydrate groups in glycoproteins of mucin for binding sites on free ConA and DOX-loaded PCL1-b-PManEA@ConA micelles. As shown in Figure 5, the binding of free ConA and DOX-loaded PCL1-b-PManEA@ConA micelles to mucin has been effectively inhibited (Figure 5, curve b), indicating the existence of ConA-mediated mucoadhesion. The release profiles together with the ConA-mediated mucoadhesive property of DOX-loaded PCL1-b-PManEA@ConA micelles are thus advantageous to sustained intravesical drug delivery. 


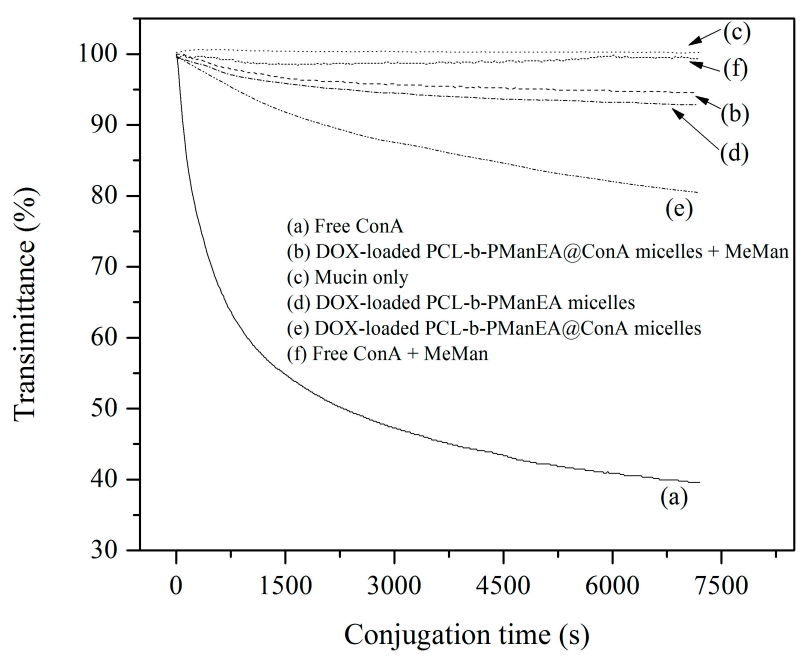

Figure 5. Turbidimetry assay experiment of DOX-loaded PCL1- $b$-PManEA micelles, and free ConA and DOX-loaded PCL1-b-PManEA@ConA micelles in the absence and presence of MeMan, with mucin.

\subsection{Cellular Uptake and In Vitro Cytotoxicity Evaluation}

The in vitro cytotoxicity of DOX-loaded PCL1-b-PManEA@ConA micelles against UMUC3 human urothelial carcinoma cell line was compared to that of free DOX and DOX-free PCL1-b-PManEA@ConA micelles. The UMUC-3 cells were treated with DOX-loaded PCL1- $b$-PManEA@ConA micelles $(1.0 \mathrm{mg} / \mathrm{mL})$ for $2 \mathrm{~h}$. The $2 \mathrm{~h}$ cellular incubation time was chosen to imitate the typical intravesical instillation period. The cellular uptake of DOX-loaded PCL1-b-PManEA@ConA micelles $(1.0 \mathrm{mg} / \mathrm{mL})$ by UMUC-3 cells was first investigated by CLSM. As shown in Figure 6a, the CLSM image shows strong red fluorescence in the cells after just $2 \mathrm{~h}$ of incubation with DOX-loaded PCL1- $b$-PManEA@ConA micelles. The red fluorescence is attributed to the internalization of micelles. The fast internalization of micelles may be due to cellular endocytosis or complexation between ConA on micelles and the D-mannose (Man) residues on cell surface glycans [41]. To demonstrate the cellular endocytosis or ConA-mediated cellular internalization of DOX-loaded PCL1-b-PManEA@ConA micelles, competitive binding assays were tested using MeMan. MeMan can compete with the Man residues on cell surface glycans for binding sites on DOX-loaded PCL1-b-PManEA@ConA micelles. Both MeMan (20 mM) and DOX-loaded PCL1-b-PManEA@ConA micelles $(1 \mathrm{mg} / \mathrm{mL})$ were cultured together with UMUC-3 cells. In comparison to the CLSM images of the UMUC-3 cells in the absence (Figure 6a) of and presence (Figure $6 \mathrm{~b}$ ) of the MeMan, no obvious decrease in the fluorescence change is observed, suggesting no significant ConA-mediated cellular internalization on the binding of the micelles with UMUC-3 cells. Thus, the interaction of the DOX-loaded PCL1-b-PManEA@ConA micelles with UMUC-3 cells is mainly due to the cellular endocytosis.

The above results have shown that the DOX-loaded PCL1- $b$-PManEA@ConA micelles can be effectively taken up by UMUC-3 cells within $2 \mathrm{~h}$. After additional $72 \mathrm{~h}$ of incubation, the in vitro cytotoxicity of free DOX, and DOX-free and DOX-loaded PCL1-b-PManEA@ConA micelles are shown in Figure 7. No obvious cytotoxicity of DOX-free PCL1-b-PManEA@ConA micelles is observed even at a concentration of $2 \mathrm{mg} / \mathrm{mL}$, indicating that DOX-free PCL1-b-PManEA@ConA micelles have excellent biocompatibility and low cytotoxicity towards UMUC-3 cells (Figure 7a). Under the same conditions, DOX-loaded PCL1- $b$-PManEA@ConA micelles show pronounced cytotoxic effects (Figure $7 \mathrm{~b}$ ). Cell viability decreased to $25.6 \%$ with DOX-loaded PCL1-b-PManEA@ConA micelles concentration of $2 \mathrm{mg} / \mathrm{mL}$. This result is consistent with the cellular uptake results, suggesting that the DOX has been efficiently delivered and released into the nuclei of UMUC-3 cells. The cytotoxicities of free DOX and DOX-loaded PCL1-b-PManEA@ConA micelles were further compared. The DOX concentrations that kill $50 \%$ of cells $\left(\mathrm{IC}_{50}\right)$ were determined to be 0.79 and $1.98 \mu \mathrm{g} / \mathrm{mL}$ for free DOX and DOX-loaded PCL1-b-PManEA@ConA micelles, respectively. Thus, the DOX-loaded 
PCL1-b-PManEA@ConA micelles system with high anti-cancer efficiency, comparable to free DOX, is an advantageous formulation for intravesical treatment of non-muscle invasive (NMI) bladder cancer.
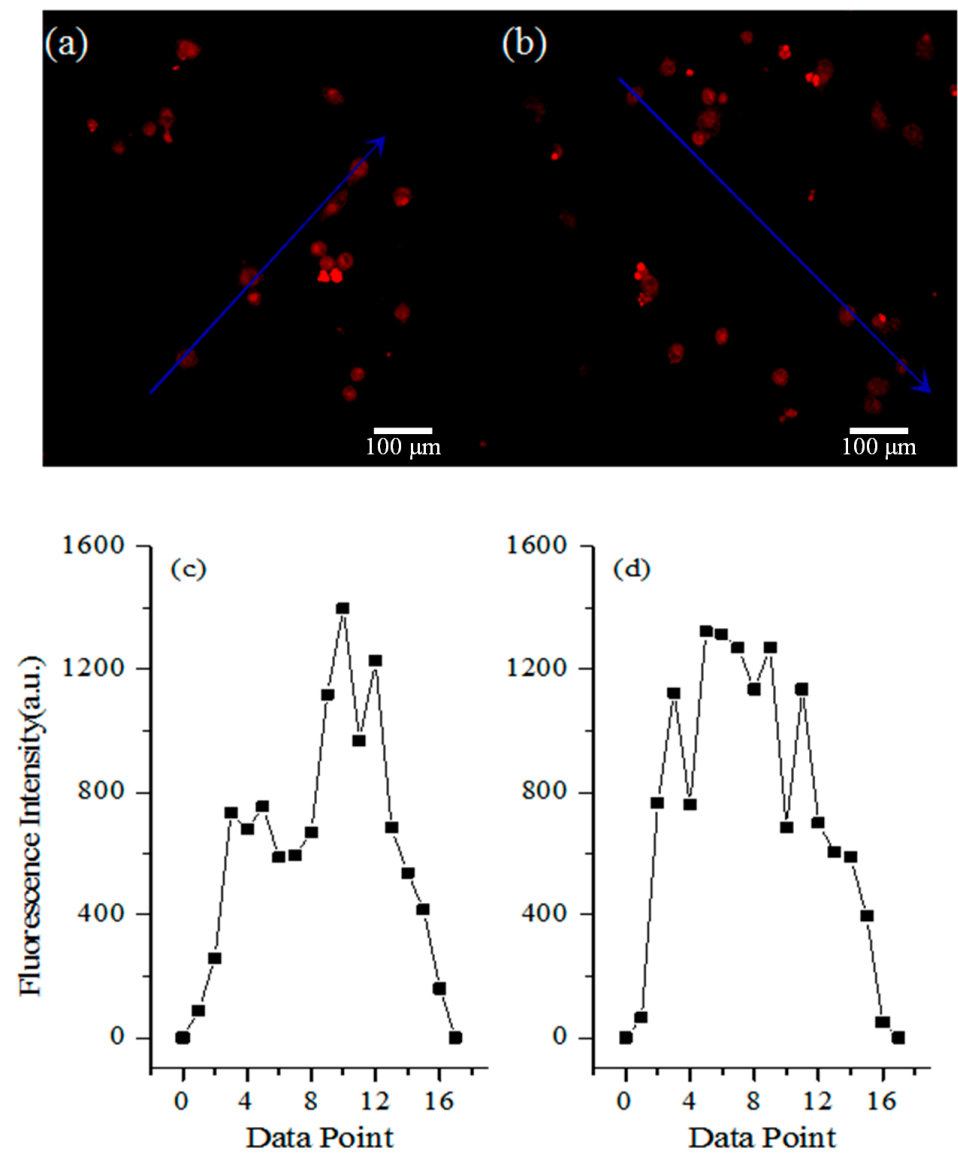

Figure 6. Confocal laser scanning microscope (CLSM) images and fluorescence profiles of UMUC3 cells incubated with: (a,c) DOX-loaded PCL1- $b$-PManEA@ConA micelles $(1 \mathrm{mg} / \mathrm{mL})$; and (b,d) DOX-loaded PCL1-b-PManEA@ConA micelles (1 mg/mL) + MeMan (20 mM) for $2 \mathrm{~h}$.
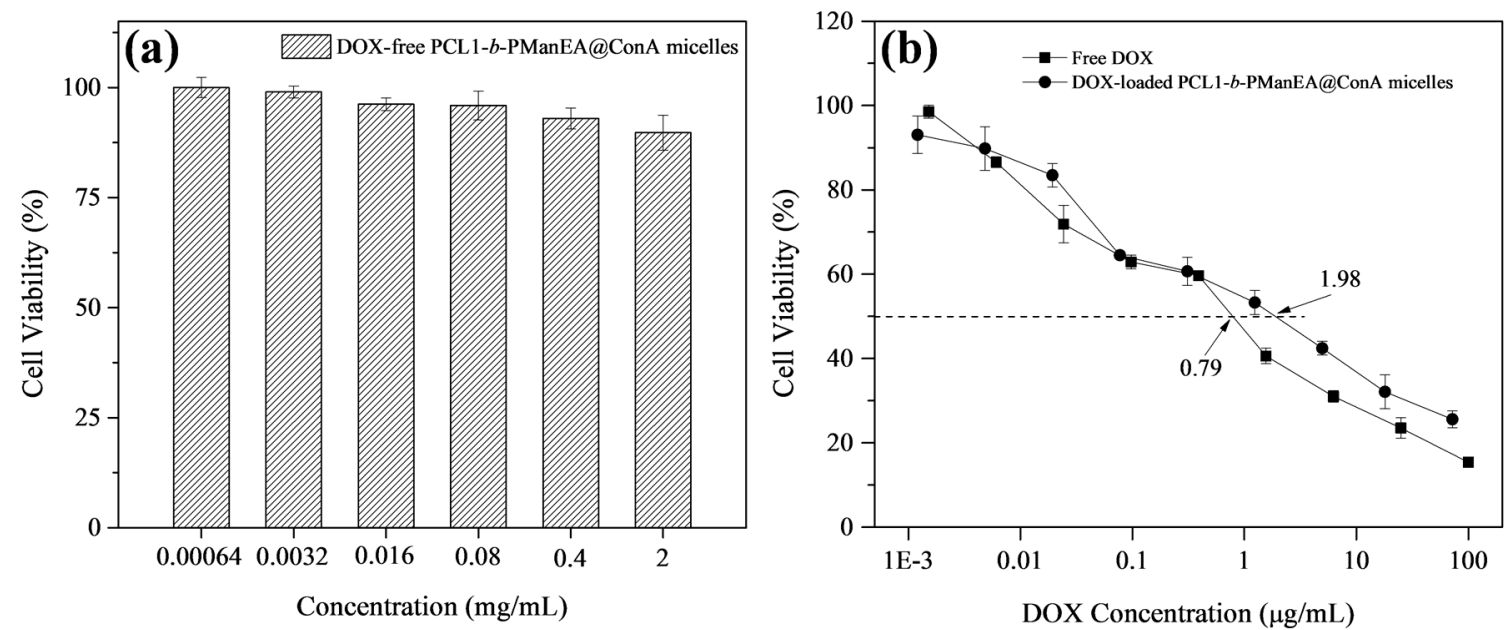

Figure 7. Viability of UMUC3 cells after incubation with: (a) DOX-free PCL1-b-PManEA@ConA micelles; and (b) free DOX and DOX-free PCL1- $b$-PManEA@ConA micelles. Cells were exposed to the free DOX or micelles for $2 \mathrm{~h}$ and further cultured with fresh DMEM for $72 \mathrm{~h}$. 


\section{Conclusions}

Amphiphilic PCL- $b$-PManEA block copolymers were synthesized and self-assembled into micelles to encapsulate anticancer drug (DOX) and conjugate ConA lectin. The resulting DOX-loaded PCL-b-PManEA@ConA micelles exhibit an initial burst release, followed by a sustained and slow release over three days in an in vitro study. The DOX-loaded PCL-b-PManEA@ConA micelles also exhibit mucoadhesive property and enhanced in vitro cytotoxicity against UMUC3 human urothelial carcinoma cells. Thus, the DOX-loaded PCL-b-PManEA@ConA micelles have promising applications in intravesical therapy of non-muscle invasive bladder cancer. To further verify the intravesical drug delivery claims in this work, in vivo animal experiments should be performed.

Supplementary Materials: The following are available online at www.mdpi.com/2073-4360/8/11/379/s1, Table S1: Characteristics of the PCL homopolymers and PCL- $b$-PPFA block copolymers, Figure S1: GPC elution curves of PCL1, PCL2 homopolymers, and PCL1- $b$-PPFA, PCL2- $b$-PPFA block copolymers, Figure S2: ${ }^{1} \mathrm{H}$ NMR spectra of (a) PCL2 homopolymer, (b) PCL2- $b$-PPFA and (c) PCL2- $b$-PManEA block copolymers, Figure S3: FT-IR spectra of (a) PCL2 homopolymer, (b) PCL2- $b$-PPFA and (c) PCL2-b-PManEA block copolymers, Figure S4: ${ }^{19}$ F NMR spectra of (a) PCL2- $b$-PPFA and (b) PCL2-b-PManEA block copolymers, Figure S5: (a,b) Hydrodynamic diameter distribution functions and (c,d) FETEM images of DOX-loaded PCL1- $b$-PManEA and PCL2- $b$-PManEA micelles, respectively, Figure S6: Evolution of mean effective diameters of DOX-loaded PCL1- $b$-PManEA and PCL2-b-PManEA micelles upon binding with ConA.

Acknowledgments: The authors would like to acknowledge the financial support from the National Natural Scientific Foundation of China (21504072) and the Program for the Fundamental Research Funds for the Central Universities (XDJK2015C068 and SWU115005).

Author Contributions: Ning Ning Li, Xue Feng Hu and Li Qun Xu designed the experiments. Ning Ning Li, Xiao Yan Cai, Jiu Cun Chen and Li Qun Xu performed the experiments and analyzed the data. Li Qun Xu and Ning Ning Li wrote the manuscript. Xue Feng Hu and Li Qun Xu contributed to the discussions.

Conflicts of Interest: The authors declare no conflict of interest.

\section{References}

1. Yu, Q.; Zhang, J.; Zhang, G.; Gan, Z. Synthesis and functions of well-defined polymer-drug conjugates as efficient nanocarriers for intravesical chemotherapy of bladder cancera. Macromol. Biosci. 2015, 15, 509-520. [CrossRef] [PubMed]

2. Pardini, B.; Allione, A.; Guarrera, S.; Turinetto, V.; Fiorito, G.; Viberti, C.; Russo, A.; Vineis, P.; Sacerdote, C.; Giachino, C.; et al. Abstract 4615: H2ax phosphorylation assays, gene expression and epigenomic profiles as markers in bladder cancer: An integrated approach. Cancer Res. 2015, 75, 4615. [CrossRef]

3. Tyagi, P.; Tyagi, S.; Kaufman, J.; Huang, L.; de Miguel, F. Local drug delivery to bladder using technology innovations. Urol. Clin. N. Am. 2006, 33, 519-530. [CrossRef] [PubMed]

4. Mugabe, C.; Matsui, Y.; So, A.I.; Gleave, M.E.; Baker, J.H.E.; Minchinton, A.I.; Manisali, I.; Liggins, R.; Brooks, D.E.; Burt, H.M. In vivo evaluation of mucoadhesive nanoparticulate docetaxel for intravesical treatment of non-muscle-invasive bladder cancer. Clin. Cancer Res. 2011, 17, 2788-2798. [CrossRef] [PubMed]

5. Davidovich-Pinhas, M.; Harari, O.; Bianco-Peled, H. Evaluating the mucoadhesive properties of drug delivery systems based on hydrated thiolated alginate. J. Control. Release 2009, 136, 38-44. [CrossRef] [PubMed]

6. Shaikh, R.; Raj Singh, T.R.; Garland, M.J.; Woolfson, A.D.; Donnelly, R.F. Mucoadhesive drug delivery systems. J. Pharm. Bioallied Sci. 2011, 3, 89-100. [PubMed]

7. Dumitriu, S. Polymeric Biomaterials; Marcel Dekker: New York, NY, USA, 2002.

8. Smart, J.D. The basics and underlying mechanisms of mucoadhesion. Adv. Drug Deliv. Rev. 2005, 57, 1556-1568. [CrossRef] [PubMed]

9. Bernkop-Schnurch, A. Thiomers: A new generation of mucoadhesive polymers. Adv. Drug Deliv. Rev. 2005, 57, 1569-1582. [CrossRef] [PubMed]

10. Leitner, V.M.; Walker, G.F.; Bernkop-Schnürch, A. Thiolated polymers: Evidence for the formation of disulphide bonds with mucus glycoproteins. Eur. J. Pharm. Biopharm. 2003, 56, 207-214. [CrossRef]

11. Anande, N.M.; Jain, S.K.; Jain, N.K. Con-A conjugated mucoadhesive microspheres for the colonic delivery of diloxanide furoate. Int. J. Pharm. 2008, 359, 182-189. [CrossRef] [PubMed] 
12. Liener, I.E.; Sharon, N.; Goldstein, I.J. The Lectins: Properties, Functions, and Applications in Biology and Medicine; Academic Press: Cambridge, MA, USA, 1986.

13. Yin, Y.S.; Chen, D.W.; Qiao, M.X.; Lu, Z.; Hu, H.Y. Preparation and evaluation of lectin-conjugated PLGA nanoparticles for oral delivery of thymopentin. J. Control. Release 2006, 116, 337-345. [CrossRef] [PubMed]

14. Wood, K.M.; Stone, G.M.; Peppas, N.A. Wheat germ agglutinin functionalized complexation hydrogels for oral insulin delivery. Biomacromolecules 2008, 9, 1293-1298. [CrossRef] [PubMed]

15. Gabor, F.; Bogner, E.; Weissenboeck, A.; Wirth, M. The lectin-cell interaction and its implications to intestinal lectin-mediated drug delivery. Adv. Drug Deliv. Rev. 2004, 56, 459-480. [CrossRef] [PubMed]

16. Chen, W.; Meng, F.H.; Cheng, R.; Deng, C.; Feijen, J.; Zhong, Z.Y. Biodegradable glycopolymer- $b$-poly $(\varepsilon-$ caprolactone) block copolymer micelles: Versatile construction, tailored lactose functionality, and hepatoma-targeted drug delivery. J. Mater. Chem. B 2015, 3, 2308-2317. [CrossRef]

17. Zhou, W.; Dai, X.H.; Dong, C.M. Biodegradable and biomimetic poly(e-caprolactone)/ poly(lactobionarnidoethyl methacrylate) biohybrids: Synthesis, lactose-installed nanoparticles and recognition properties. Macromol. Biosci. 2008, 8, 268-278. [CrossRef] [PubMed]

18. Gentsch, R.; Pippig, F.; Nilles, K.; Theato, P.; Kikkeri, R.; Maglinao, M.; Lepenies, B.; Seeberger, P.H.; Borner, H.G. Modular approach toward bioactive fiber meshes carrying oligosaccharides. Macromolecules 2010, 43, 9239-9247. [CrossRef]

19. Eberhardt, M.; Mruk, R.; Zentel, R.; Théato, P. Synthesis of pentafluorophenyl(meth)acrylate polymers: New precursor polymers for the synthesis of multifunctional materials. Eur. Polym. J. 2005, 41, 1569-1575. [CrossRef]

20. Stickler, D.J.; Morgan, S.D. Modulation of crystalline proteus mirabilis biofilm development on urinary catheters. J. Med. Microbiol. 2006, 55, 489-494. [CrossRef] [PubMed]

21. Von der Ehe, C.; Weber, C.; Gottschaldt, M.; Schubert, U.S. Immobilized glycopolymers: Synthesis, methods and applications. Prog. Polym. Sci. 2016, 57, 64-102. [CrossRef]

22. $\mathrm{Xu}, \mathrm{L} . \mathrm{Q}$. Ruthenium(II)-terpyridine complexes-containing glyconanoparticles for one- and two-photon excited fluorescence imaging. Eur. Polym. J. 2015, 71, 279-288. [CrossRef]

23. Xu, L.Q.; Huang, C.; Wang, R.; Neoh, K.G.; Kang, E.T.; Fu, G.D. Synthesis and characterization of fluorescent perylene bisimide-containing glycopolymers for escherichia coli conjugation and cell imaging. Polymer 2011, 52, 5764-5771. [CrossRef]

24. Lee, Y.; Hanif, S.; Theato, P.; Zentel, R.; Lim, J.; Char, K. Facile synthesis of fluorescent polymer nanoparticles by covalent modification-nanoprecipitation of amine-reactive ester polymers. Macromol. Rapid Common. 2015, 36, 1089-1095. [CrossRef] [PubMed]

25. Xu, L.Q.; Chen, J.C.; Qian, S.S.; Zhang, A.K.; Fu, G.D.; Li, C.M.; Kang, E.T. Pegylated metalloporphyrin nanoparticles as a promising catalyst for the heterogeneous oxidation of cyclohexene in water. Macromol. Chem. Phys. 2015, 216, 417-426. [CrossRef]

26. Xu, L.Q.; Jiang, H.; Neoh, K.G.; Kang, E.T.; Fu, G.D. Poly(dopamine acrylamide)-co-poly(propargyl acrylamide)-modified titanium surfaces for 'click' functionalization. Polym. Chem. 2012, 3, 920-927. [CrossRef]

27. Sun, P.J.; Zhang, Y.; Shi, L.Q.; Gan, Z.H. Thermosensitive nanoparticles self-assembled from pcl- $b$-peo- $b$-pnipaam triblock copolymers and their potential for controlled drug release. Macromol. Biosci. 2010, 10, 621-631. [CrossRef] [PubMed]

28. GuhaSarkar, S.; Banerjee, R. Intravesical drug delivery: Challenges, current status, opportunities and novel strategies. J. Control. Release 2010, 148, 147-159. [CrossRef] [PubMed]

29. Wang, F.; Bronich, T.K.; Kabanov, A.V.; Rauh, R.D.; Roovers, J. Synthesis and evaluation of a star amphiphilic block copolymer from poly( $\varepsilon$-caprolactone) and poly(ethylene glycol) as a potential drug delivery carrier. Bioconj. Chem. 2005, 16, 397-405. [CrossRef] [PubMed]

30. Mohan, P.; Rapoport, N. Doxorubicin as a molecular nanotheranostic agent: Effect of doxorubicin encapsulation in micelles or nanoemulsions on the ultrasound-mediated intracellular delivery and nuclear trafficking. Mol. Pharm. 2010, 7, 1959-1973. [CrossRef] [PubMed]

31. Wang, D.L.; Su, Y.; Jin, C.Y.; Zhu, B.S.; Pang, Y.; Zhu, L.J.; Liu, J.Y.; Tu, C.L.; Yan, D.Y.; Zhu, X.Y. Supramolecular copolymer micelles based on the complementary multiple hydrogen bonds of nucleobases for drug delivery. Biomacromolecules 2011, 12, 1370-1379. [CrossRef] [PubMed] 
32. Ting, S.R.S.; Chen, G.J.; Stenzel, M.H. Synthesis of glycopolymers and their multivalent recognitions with lectins. Polym. Chem. 2010, 1, 1392-1412. [CrossRef]

33. Krimmer, S.G.; Pan, H.Z.; Liu, J.H.; Yang, J.Y.; Kopecek, J. Synthesis and characterization of poly( $\varepsilon$-caprolactone)-block-poly $n$-(2-hydroxypropyl)methacrylamide micelles for drug delivery. Macromol. Biosci. 2011, 11, 1041-1051. [CrossRef] [PubMed]

34. Allen, C.; Maysinger, D.; Eisenberg, A. Nano-engineering block copolymer aggregates for drug delivery. Colloids Surf. B Biointerfaces 1999, 16, 3-27. [CrossRef]

35. Valimaa, T.; Laaksovirta, S. Degradation behaviour of self-reinforced 80L/20G PLGA devices in vitro. Biomaterials 2004, 25, 1225-1232. [CrossRef] [PubMed]

36. Lemoine, D.; Francois, C.; Kedzierewicz, F.; Preat, W.; Hoffman, M.; Maincent, P. Stability study of nanoparticles of poly(E-caprolactone), poly(D,L-lactide) and poly(D,L-lactide-co-glycolide). Biomaterials 1996, 17, 2191-2197. [CrossRef]

37. Liu, Y.; Steele, T.; Kissel, T. Degradation of hyper-branched poly(ethylenimine)-graft-poly(caprolactone)-blockmonomethoxyl-poly (ethylene glycol) as a potential gene delivery vector. Macromol. Rapid Commun. 2010, 31, 1509-1515. [CrossRef] [PubMed]

38. Bhaw-Luximon, A.; Meeram, L.M.; Jugdawa, Y.; Helbert, W.; Jhurry, D. Oligoagarose-g-polycaprolactone loaded nanoparticles for drug delivery applications. Polym. Chem. 2011, 2, 77-79. [CrossRef]

39. Wang, X.-L.; Huang, Y.; Zhu, J.; Pan, Y.-B.; He, R.; Wang, Y.-Z. Chitosan-graft-poly(p-dioxanone) copolymers: Preparation, characterization, and properties. Carbohydr. Res. 2009, 344, 801-807. [CrossRef] [PubMed]

40. Xu, Y.; Takvorian, P.M.; Cali, A.; Orr, G.; Weiss, L.M. Glycosylation of the major polar tube protein of encephalitozoon hellem, a microsporidian parasite that infects humans. Infect. Immun. 2004, 72, 6341-6350. [CrossRef] [PubMed]

41. Wu, P.; Chen, X.; Hu, N.; Tam, U.C.; Blixt, O.; Zettl, A.; Bertozzi, C.R. Biocompatible carbon nanotubes generated by functionalization with glycodendrimers. Angew. Chem. Int. Ed. 2008, 47, 5022-5025. [CrossRef] [PubMed]

(C) 2016 by the authors; licensee MDPI, Basel, Switzerland. This article is an open access article distributed under the terms and conditions of the Creative Commons Attribution (CC-BY) license (http://creativecommons.org/licenses/by/4.0/). 